\title{
IMPLEMENTASI MODEL KARISMA MATEMATIKA SEBAGAI PENANAMAN KARAKTER ANAK
}

\author{
Rifaatul Mahmudah \\ PGSD Universitas Hamzanwadi \\ Email : rifadikdas@gmail.com
}

\begin{abstract}
Abstrak
Penelitian ini bertujuan untuk mengimplementasikan model karisma sebagai penanaman karakter anak menggunakan pembelajaran tematik untuk meningkatkan hasil belajar siswa. Subyek uji coba di kelas IV MI NW Korleko. Data dianalisis dengan deskriptif, uji ketuntasan belajar menggunakan uji t, uji proporsi z (Uji Ketuntasan Individu), Uji Banding (Uji Perbedaan Hasil Belajar Kelompok Eksperimen dengan Kelas Kontrol), Uji Regresi . Hasil penelitian menunjukkan bahwa: (1) Model karisma yang diimplementasikan direspon baik oleh Guru, karena karakter atau akhlak anak yang diinginkan mulai tertanam. (2) Hasil belajar (HB) mencapai ketuntasan klasikal, uji proporsi menunjukkan Hasil belajar siswa memenuhi standar kriteria minimum, rata-rata hasil belajar kelas eksperimen lebih baik dari kelas kontrol. pada uji regresi diperoleh simpulan bahwa karakter siswa berpengaruh positif terhadap HB. Adanya peningkatan HB kelas eksperimen.
\end{abstract}

Kata Kunci: implementasi model karisma, penanaman karakter

\section{PENDAHULUAN}

Dalam konteks pendidikan karakter UU No 20 tahun 2003 tentang sisdiknas pada pasal 3 menyebutkan bahwa pendidikan nasional berfungsi mengembangkan kemampuan dan membentuk watak serta peradaban bangsa yang bermartabat dalam rangka mencerdaskan kehidupan bangsa, bertujuan untuk berkembangnya potensi peserta didik agar menjadi manusia yang beriman dan bertakwa kepada Tuhan Yang Maha Esa, berakhlak mulia, sehat, berilmu, cakap, kreatif, mandiri, dan menjadi warga negara yang demokratis dan bertanggung jawab.

Undang-undang tersebut mengamanahkan agar pendidikan tidak hanya membentuk manusia Indonesia yang cerdas, namun juga berkepribadian atau berkarakter, yang menanamkan nilai-nilai, sehingga bangsa Indonesia akan menjadi bangsa yang cerdas dan berkepribadian luhur (Suyanto, 2009).

Pendidikan merupakan usaha sadar manusia untuk mengembangkan potensi yang dimiliki secara efektif dan optimal untuk menanamkan nilai 
kehidupan. Sedangkan karakter adalah wujud pemahaman dan pengetahuan seseorang tentang nilai-nilai mulia dalam kehidupan yang bersumber dari tatanan budaya, agama dan kebangsaan serta diwujudkan dalam sikap, perilaku dan kepribadian seharihari (Muchayat, 2011: 201).

Dewasa ini, pendidikan karakter menjadi wacana yang ramai dibicarakan oleh tenaga pendidik dan masyarakat. Data hasil survei Nasional tahun 2003-2006 tentang peredaran dan penyalah gunaan narkoba pada kelompok pelajar dan mahasiswa cenderung meningkat (Badan Narkotika Nasional: 2006).

Pendidikan karakter adalah sebuah sistem yang menanamkan nilai-nilai karakter pada siswa melalui pengembangan potensi yang dimiliki serta adanya kemauan dan tindakan untuk melaksanakan nilai-nilai (Aunillah, 2011: 18). Sejalan dengan itu Berkowitz (2005:2) yakni pendidikan karakter mengajarkan siswa tentang nilai dasar manusia, diantaranya jujur, ramah, murah hati, keteguhan hati, kebebasan, persamaan dan saling menghormati.

Pendidikan moral dan karakter sangat penting untuk perkembangan moral siswa di dalam melakukan interaksi sosial sebagai identitas tujuan lingkungan pendidikan yang afektif (Narvaez dan Nucci, 2012).

Pendidikan karakter di Indonesia dirasakan amat perlu pengembangannya. Tanpa adanya karakter yang jelas maka siswa akan mengalami kebingungan terhadap keadaannya dan sulit untuk menentukan apa yang seharusnya dilakukan (Hamdi, 2011:1).

Pendidikan yang diselenggarakan diharapkan dapat mengembangkan karakter siswa sehingga mampu bersaing, beretika, bermoral, sopan santun dan berinteraksi dengan masyarakat (Kemendiknas, 2010:4).

Salah satu model pembelajaranyang menanamkan nilai karakter di dalam mata pelajaran adalah pembelajaran karisma. Karisma merupakan akronim dari Karakter Terintegrasi dalam Mata Pelajaran (Rusilowati, et al. 2012). Dengan mengimplementasi model karisma akan menyentuh internalisasi dan pengalaman nyata peserta didik yang menjadi salah satu bagian dari keluarga dan masyarakat. 
Sejalan dengan hal tersebut Cohen (2006:201) " goal of education neeed to be reframe to prioritize not only akademic learning but also social, emotional and ethnical competencies". Sintak karisma terdiri dari kenalkan, kaitkan, terapkan, balikkan, dan kembangkan.

Arti pendidikan karakter secara terintegrasi di dalam proses pembelajaran adalah pengenalan nilainilai, fasilitasi diperolehnya kesadaran akan pentingnya nilai-nilai, dan penginternalisasian nilai-nilai ke dalam tingkah laku peserta didik sehari-hari melalui proses pembelajaran, baik yang berlangsung di dalam maupun di luar kelas pada semua mata pelajaran.

Pembelajaran nilai-nilai karakter tidak hanya pada tataran kognitif, tetapi menyentuh internalisasi dan pengalaman nyata siswa. Nilai-nilai matematika yang dimaksud terkait dengan hakikat matematika yang berangkat dari bagaimana para matematikawan yang berbeda budaya mengembangkan matematika (Bishop, 1999).

Isu sentral yang sering mewarnai pembelajaran disekolah dasar adalah pembelajaran tematik. Ini Dilihat dari tidak mudahnya guru dalam menyiapkan bahan ajar serta materi yang akan disampaikan, sehingga berdampak pada rendahnya kualitas hasil belajar siswa. Hasil belajar matematika siswa disebabkan karena faktor internal lebih baik dibandingkan dengan faktor eksternal House (2006: 32).

Pada kegiatan akhir pembelajaran dilakukan evaluasi untuk melihat hasil belajar siswa, pembelajaran berjalan efektif atau tidak yang didasarkan pada pengamatan tingkah laku, melalui stimulus respons dan belajar bersyarat.

Winkel

(1999:34) mengemukakan bahwa hasil belajar merupakan bukti keberhasilan yang telah dicapai seseorang dimana setiap kegiatan belajar dapat menimbulkan suatu perubahan yang khas. Widaningsih (2005) meninjau dari dimensi kompetensi yang ingin dicapai yaitu (1) kompetensi ranah kognitif, (2) kompetensi ranah afektif, dan (3) kompetensi ranah psikomotorik.

Sekolah Dasar merupakan waktu yang tepat untuk diberikan penekanan pada aspek kognitif, afektif, dan psikomotorik secara proporsional 
(Tim Pengembangan Kurikulum, 2013). Untuk merealisasikan tiga ranah tersebut SD dituntut menggunakan pembelajaran Tematik. Dalam menyampaikan pembelajaran guru menentukan tema dan dapat mengintegrasikan beberapa pelajaran dalam satu tema, sehinga guru tidak banyak mengulang pelajaran lainnya.

Pembelajaran tematik adalah pembelajaran terpadu yang menggunakan tema untuk mengaitkan beberapa mata pelajaran (Wirahayu, dkk, 2014:3). Pembelajaran tematik sudah sepantasnya direalisasikan melaui implementasi model pembelajaran karisma dalam menanmkan karakter anak atau peserta didik, karena ini sudah lama mendapat respon yang sangat baik dari guru, siswa bahkan orang tua (Min, 2012:279).

Dalam tema pembelajaran tematik yang berkaitan dengan norma dan etika pada dasarnya tidak ditemukan secara langsung namun esensi dari tema itu bisa dieksplisitkan dengan mengembangkan pembelajaran model Karisma.

Dari beberapa persepsi di atas, pendidikan karakter di Indonesia dirasakan amat perlu pengembangannya yang tidak terlepas dari pendidik, keluarga dan masyarakat, karena pendidikan kita dinilai terlalu menonjolkan kognisi tetapi minus nilai dan moral (Agboola \& Chen 2012).

Matematika sebagai mata pelajaran wajib disekolah memiliki peran penting dalam pembentukan karakter siswa diantaranya disiplin, jujur, toleransi, kerja keras, kreatif, mandiri, rasa ingin tahu, tanggung jawab dan lain-lain. Kurikulum mata pelajaran matematika membentuk karakter-karakter siswa agar menjadi manusia yang tangguh, dan mampu menghadapi persaingan di zaman yang sangat penuh dengan persaingan.

Salah satu aspek afektif yang dapat dikembangkan dalam proses pembelajaran adalah karaktersitik disiplin belajar siswa. karaktersitik disiplin belajar diartikan sebagai tindakan yang menunjukan perilaku tertib dan patuh pada berbagai ketentuan dan peraturan.

$$
\text { Menurut Bahri (2012 : 12) }
$$
adalah suatu tata tertib yang dapat mengatur tatanan kehidupan pribadi dan kelompok. Sedangkan menurut Rasdiyanah (1995:28) disiplin adalah kepatuhan untuk menghormati dan 
melaksanakan suatu sistem yang mengharuskan orang untuk tunduk pada keputusan, perintah atau peraturan yang berlaku.

$$
\text { Tulus (2004 : 37) }
$$

mengungkapkan ada beberapa alasan pentingnya disiplin belajar diantaranya adalah:

1. Dengan disiplin yang muncul dari kesadaran diri diharapkan siswa dapat berhasil dalam belajar, sebaliknya siswa yang kerap kali melanggar ketentuan sekolah pada umumnya terhambat optimalisasi potensi dan prestasinya.

2. Tanpa disiplin yang baik, suasana sekolah dan kelas menjadi kurang kondusif bagi kegiatan pembelajaran. Secara positif, disiplin memberikan dukungan lingkungan yang tenang dan tertib bagi proses pembelajaran.

3. Orang tua senantiasa berharap di sekolah agar anak-anak dibiasakan dengan norma-norma, nilai kehidupan dan disiplin, sehingga diharapkan anak-anak menjadi individu yang tertib, teratur dan disiplin.

4. Disiplin merupakan jalan bagi siswa untuk suskes dalam belajar dan pada saat masuk dalam dunia kerja.

Beberapa pendapat di atas dapat diambil kesimpulan bahwa disiplin belajar merupakan tindakan yang didasarkan atas ketaatan dan kepatuhan seseorang untuk melaksanakan peraturan tanpa unsur paksaan yang timbul akibat stimulus dari luar atau pun dari dirinya sendiri, sehingga akan terbentuk siswa yang tertib, teratur dan disiplin.

Penelitian tentang implementasikan model pembelajaran karisma dalam membangun karakter anak menggunakan pembelajaran tematik untuk meningkatkan hasil belajar siswa telah banyak dilakukan oleh para peneliti dalam bidang pendidikan yang menggunakan berbagai model dan metode pembelajaran. Adapun kajian penelitian yang relevan dengan penelitian sebelumnya antara lain.

Narvaez dan Nucci (2011) melakukan penelitian di Turkey Maslan tentang pendidikan karakter. Dari hasil penelitian dapat disimpulkan pendidikan moral dan karakter sangat penting untuk perkembangan moral siswa di dalam 
melakukan interaksi sosial yang merupakan identitas sebagai tujuan pendidikan yang dapat mewujudkan lingkungan yang afektif.

Penelitian oleh Min (2012:279) menyimpulkan penelitiannya terhadap pemahaman dan praktik pada pembelajaran tematik kepada guru mendapat respon yang sangat baik. Yakni dapat meningkatkan pemahamandan praktek terhadap pembelajaran tematik dalam pengajaran sehari-hari dan proses pembelajarandi kelas.

Rahmadani (2012) melakukan penelitian tentang penanaman nilai karakter di SD, bahwa perangkat pembelajaran yang dikembangkan efektif dapat meningkatkan hasil belajar dan motivasi siswa sangat tinggi yang menunjukkan ketuntasan kelas $88,37 \%$ dan motivasi siswa $25,58 \%$.

Agboola \& Chen (2012) melakukan penelitian pendidikan karakter pada mahasiswa Eropa menyimpulkan bahwa pentingnya pengembangan nilai karakter di dalam sekolah yang dapat mempengaruhi prilaku siswa secara efektif yang tidak terlepas dari dukungan guru, kepala sekolah, keluarga dan masyarakat.
Murtijah

(2013:154)

menyimpulkan hasil pengembangan perangkat pembelajaran dan hasil penelitian yang telah dilakukan dengan pendekatan kontekstual kelas $\mathrm{V}$ valid dan efektif. Hasil belajar siswa menggunakan pengembangan perangkat lebih baik dari siswa yang menggunakan pembelajaran konvensional.

Pada penelitian ini berbeda dengan penelitian sebelumnya. Penelitian ini mengimplementasikan model pembelajaran karisma sebagai penanaman karakter anak menggunakan pembelajaran tematik untuk meningkatkan hasil belajar siswa.

Dari uraian diatas dirasa sangat urgen untuk tujuan penelitian ini segera dituntaskan dalam "Implementasi Model Karisma Matematika Sebagai Penanaman Karakter Anak melalui pembelajaran tematik"

\section{METODE PENELITIAN}

Penelitian ini termasuk dalam jenis penelitian kuantitatif. Subjek penelitian adalah seluruh siswa kelas IV MI NW Korleko semester genap Tahun Pelajaran 2015/2016. Teknik 
pengambilan sampel dengan class random sampling.

\section{Uji Proporsi (Uji Ketuntasan Individu)}

Uji proporsi digunakan untuk mengetahui ketuntasan hasil belajar matematika siswa secara klasikal. Menurut Bloom sebagaimana yang dikutip oleh Winkel (2007: 466) adalah apabila $75 \%$ siswa mencapai nilai ketuntasan individu yaitu 70 . Namun pertimbangan tingkat kemampuan akademik (intake) siswa di lokasi penelitian sehingga dalam penelitian ini ditetapkan standar KKM sebesar 65.

Rumusan hipótesis :

$\mathrm{H}_{0}: \pi \leq 69 \%$ (banyaknya siswa yang mencapai nilai KKM paling tinggi 69\%).

$\mathrm{H}_{1}: \pi>69 \%$ (banyaknya siswa yang mencapai nilai KKM lebih dari $69 \%)$.

Rumus uji statistik yang digunakan adalah $z_{\text {hitung }}=\frac{\frac{x}{n}-\pi_{0}}{\sqrt{\frac{\pi_{0}\left(1-\pi_{0}\right)}{n}}}$

Terima $\mathrm{H}_{0}$ jika $z_{\text {hitung }} \leq z_{\text {tabel }}$ dengan taraf kesukaran 5\%. Sebaliknya terima $\mathrm{H}_{1}$ yang berarti lebih dari $69 \%$ siswa yang mendapat nilai HB minimal 65.

2. Uji Banding (Uji Perbedaan Hasil Belajar Kelompok Eksperimen dengan Kelas Kontrol)

Uji banding ini digunakan untuk membandingkan hasil belajar matematika siswa di kelas eksperimen dan kontrol dilakukan dengan uji-t. Dengan mengasumsikan bahwa kedua kelas mempunyai varians yang sama, dalam penelitan ini rumus uji statistik yang digunakan adalah Rumus uji statistik untuk kasus varians sama: $t=\frac{\overline{x_{1}}-\overline{x_{2}}}{\sqrt{s^{2}\left(\frac{1}{n_{1}}+\frac{1}{n_{2}}\right)}}$ dimana

$$
s^{2}=\frac{\left(n_{1}-1\right) s_{1}{ }^{2}+\left(n_{2}-1\right) s_{2}{ }^{2}}{n_{1}+n_{2}-2} \text {. }
$$

Rumusan hipotesis:

$\mathrm{H}_{0}: \mu_{1} \leq \mu_{2}$ (rata-rata hasil belajar matematika siswa yang menggunakan pembelajaran model Karisma lebih rendah atau sama dengan hasil belajar matematika siswa yang diajarkan dengan pembelajaran konvensional).

$\mathrm{H}_{1}: \mu_{1}>\mu_{2}$ (rata-rata hasil belajar matematika siswa yang menggunakan pembelajaran model Karisma lebih tinggi 
dari pada hasil belajar matematika siswa yang diajarkan dengan pembelajaran konvensional).

$\mathrm{H}_{0}$ diterima jika $t_{h i t} \leq t_{\text {tab }}$ yang artinya rata-rata hasil belajar matematika siswa kelas eksperimen tidak lebih baik dari hasil belajar matematika siswa kelas kontrol. $t_{t a b}$ didapat dari daftar distribusi $t$ dengan taraf kesalahan $5 \%$ dan $\mathrm{dk}=\left(\mathrm{n}_{1}+\mathrm{n}_{2^{-}}\right.$

2) (Sukestiyarno, 2012).

\section{Uji Regresi}

Untuk mengetahui adanya pengaruh antara Karisma (disiplin belajar) siswa terhadap HB siswa secara signifikan.

4. Uji Normalitas Gain (Uji Peningkatan Hasil Belajar Siswa)
Peningkatan hasil belajar siswa dalam penelitian ini dianalisis berdasarkan rata-rata nilai Gain yang dinormalisasi. Untuk melakukan uji Normalitas Gain, data yang digunakan adalah data pretes (tes awal) dan posttes (tes akhir) dengan menggunakan rumus Gain ternormalisasi $(g)$, sebagai berikut :

$$
g=\frac{S_{f}-S_{i}}{100-S_{i}}(\text { Hake, 1998: 65) }
$$

Keterangan:

$\mathrm{S}_{\mathrm{f}}=$ final test (skor posttest)

$\mathrm{S}_{\mathrm{i}}=$ initial test (skor pretest)

$\mathrm{g}=$ gain (peningkatan)

Untuk memberikan interpretasi terhadap nilai gain yang didapatkan digunakan acuan kriteria nilai Gain ( $g$ ) disajikan dalam Tabel 3.11.

\begin{tabular}{|c|c|c|}
\hline No & Nilai Gain & Kriteria \\
\hline 1 & $g \geq 0,70$ & $\begin{array}{c}\text { Peningkatan } \\
\text { Tinggi }\end{array}$ \\
\hline 2 & $0,30 \leq g<0,70$ & $\begin{array}{l}\text { Peningkatan } \\
\text { Sedang }\end{array}$ \\
\hline 3 & $g<0,33$ & $\begin{array}{c}\text { Peningkatan } \\
\text { Rendah }\end{array}$ \\
\hline
\end{tabular}

(Hake, 1998: 65)

Dalam penelitian ini tes hasil belajar matematika siswa dikatakan

\section{HASIL DAN PEMBAHASAN}

meningkat jika kriteria Gain mencapai minimal sedang.
Pada table 0.1. Dijelaskan nilai hitung uji proporsi dan uji banding sebagai berikut: 
Tabel 0.1. Uji Proporsi dan Uji Banding

\begin{tabular}{cccccc}
\hline No & Uji Statistik & Nilai Hitung & Nilai Tabel & Hipotesis & Keputusan \\
\hline 1. & Uji proporsi & 2.03 & $\mathbf{1 , 6 4 5}$ & $t_{\text {hitung }}>t_{\text {tabel }}$ & Tolah $\mathrm{H}_{0}$ \\
2. & Uji banding & 4,94 & 1,68 & $z_{\text {hitung }}>z_{\text {tabel }}$ & Tolah $\mathrm{H}_{0}$ \\
\hline
\end{tabular}

Uji proprsi menunjukkan lebih dari $69 \%$ siswa kelas eksperimen yang mencapai KKM 65. Ketercapaian hasil belajar ini karena dalam proses pembelajaran tidak lepas dari model pembelajaran yang diimplementasikan. Hal ini sejalan dengan hasil penelitian Nayazik (2013:93) menunjukkan bahwa kelas eksperimen tuntas belajar lebih dari yang sudah ditetapkan dalam menanamkan karakter belajar matematika siswa.

Penelitian relevan lainnya oleh Akbar (2009:148) mengembangkan pembelajaran tematik menunjukkan pencapaian kompetensi siswa mencapai ketuntasan di kelas eksperimen.

Uji banding pada tabel 0.1 . menunjukkan kelas eksperimen lebih baik dibanding dengan kelas kontrol. Perbedaan ini terjadi karena perbedaan perlakuan dalam proses pembelajaran.

Terdapat pengaruh karakter disiplin belajar terhadap hasil belajar siswa. Implementasi model karisma matematika sebagai penanaman karakter anak memberi kontribusi positif terhadap peningkatan hasil belajar matematika siswa.

Berikut keterangannya dalam tabel 0.2 .

Tabel 0.2. Output Model Summary

\begin{tabular}{ccccc}
\hline Model & R & R Square & Adjusted R Square & $\begin{array}{c}\text { Std. Error of the } \\
\text { Estimate }\end{array}$ \\
\hline 1 & $.815^{\mathrm{a}}$ & .664 & .645 & 5.266 \\
\hline
\end{tabular}

Berdasarkan Tabel di atas diperoleh hasil R Square pada model 1 variabel karakter sebesar 0.664. Variabel karakter mempengaruhi hasil belajar sebesar 0.664 atau $66.4 \%$.
Adanya peningkatan hasil belajar yang ditunjukkan dalam tabel. 0.3. 
Tabel 0.3. Hasil Gain Belajar Siswa

Kelas Eksperimen

Kelas Kontrol

\begin{tabular}{ccccccc}
\hline Ket. & Pretest & Posttest & Gain & Pretest & Posttest & Gain \\
jumlah & 772,05 & 1489,36 & 11,73 & 818,54 & 1470,21 & 9,75 \\
Rata2 & 38,60 & 74,47 & 0,59 & 34,11 & 61,26 & 0,41 \\
\hline
\end{tabular}

Hasil perhitungan uji Gain menunjukkan bahwa kedua kelas terjadi peningkatan, peningkatan hasil belajar kelas eksperimen dengan ratarata 0,59 dan kelas kontrol dengan peningkatan rata-rata 0,41 . Hasil peningkatan ini sejalan dengan Rahmadani (2012) tentang penanaman nilai karakter pada siswa SDN 01 Semarang bahwa perangkat pembelajaran yang dikembangkan efektif dapat meningkatkan hasil belajar dan motivasi siswa sangat tinggi.

\section{SIMPULAN}

Berdasarkan hasil penelitian setelah dianalisis dan dilakukan pembahasan sesuai dengan teori yang relevan, maka dapat disimpulkan Implementasi model karisma matematika sebagai penanaman karakter anak dengan pembelajaran tematik pada kelas IV MI/NW Korleko dikatakan sangat efektif atau berhasil, karena memenuhi kriteria sebagai berikut:

1. Diperolehnya skor hasil belajar matematika siswa yang melampaui nilai KKM 65 dan lebih dari 69\% dari seluruh siswa di kelas eksperimen mencapai nilai KKM.

2. Terdapat perbedaan yang signifikan antara kelas yang diajarkan dengan model Karisma berbasis kontekstual dengan kelas yang diajarkan dengan model konvensional, artinya hasil HB siswa pada pembelajaran tematik pada kelas eksperimen lebih baik dari kelas kontrol. Perbedaan ini dapat dilihat dari rata-rata kelas kontrol 61,26 dan kelas eksperimen rata-ratanya adalah 74,47 .

3. Terdapat pengaruh antara karakter disiplin belajar terhadap hasil belajar matematika siswa. Besarnya pengaruh adalah $79,6 \%$ terhadap HB matematika siswa

4. Terjadi peningkatan hasil belajar matematika siswa pada kelas eksperimen dengan rata-rata 


$$
\begin{aligned}
& \text { sebesar } 0,59 \text { (sedang) dan } \\
& \text { peningkatan hasil belajar } \\
& \text { matematika siswa pada kelas } \\
& \text { kontrol dengan rata-rata } 0,41 \text {. }
\end{aligned}
$$

5. Uji banding peningkatan hasil belajar matematika kelas eksperimen dan kelas kontrol menunjukkan rata-rata peningkatan hasil belajar matematika siswa yang diajarkan dengan Karisma lebih baik dari siswa yang diajarkan dengan model konvensional.

\section{DAFTAR PUSTAKA}

Agboola, A. \& Chen, K. T. 2012. “ Bring Character Education Into Classroom". European Journal Narvaez, D. \& Nucci, L.P. 2012. "Handbook Of Moral And Character Education". International Journal of Instruction, 4 (2), 212-214.

Akbar, S \& Sutama, I. W. "Pengembangan Model Pembelajaran Tematik Untuk Kelas 1 dan Kelas 2 Sekolah Dasar".Jurnal Penelitian Kependidikan, No 2, Hal 140151.

Aunillah, N. I. 2011. Panduan Menerapkan Pendidikan Karakter Disekolah. Jogjakarta: Diva Press.

Badan Narkotika Nasional (BNN). 2006.Hasil Survei Penyalah Gunaan dan Peredaran Gelap Narkoba Pada Kelompok Pelajar dan Mahasiswa Di 33 Propinsi di Indonesia Tahun.
Bahri, S. 2002. Rahasia Sukses Belajar. Jakarta.PT. Rineka Cipta.

Badan Narkotika Nasional (BNN). 2006.Hasil Survei Penyalah Gunaan dan Peredaran Gelap Narkoba Pada Kelompok Pelajar dan Mahasiswa Di 33 Propinsi di Indonesia Tahun.

Bahri, S. 2002. Rahasia Sukses Belajar. Jakarta.PT. Rineka Cipta.

Berkowitz, M. W. \& Bier, M. C. 2005. What Work In Carachter Education: A Research-Driven Guide For Education. Character Education Parthenership.

Hamdi, Syukrul. 2011. "Membangun Karakter Siswa Dalam Pembelajaran Matematika Melalui CTL Berbasis Kecerdasan Majemuk". Makalah. Seminar Nasional Matematika dan Pendidikan di UNY Yogyakarta. Yogyakarta, 3 Desember.

House, J.D. 2006. Mathematics Beliefs and Archievement of Elementary School Students in Japan and the United States: Results From the Third International Mathematics and Science Study. The Journal of Genetic Psychology, 167 (1), 31-45.

Kemendiknas. 2010. Grand Desaign Pendidikan Karakter. Jakarta Dirjen Pembinaan Sekolah Menengah Pertama. Kemdikbud. Draf kurikulum 2013. 